\title{
Managing Ambient Air Quality Using Ornamental Plants-An Alternative Approach
}

\author{
Manish Kapoor \\ Department of Botany, Punjabi University, India
}

Copyright $(\mathrm{C} 2017$ by authors, all rights reserved. Authors agree that this article remains permanently open access under the terms of the Creative Commons Attribution License 4.0 International License

\begin{abstract}
Air quality management involves the determination of the relative contribution of current or future source emissions at receptor sites to ground level pollutant concentrations coupled with implementation of effective management plan to reduce emission level. From the last few decades, urban air pollution has become an inevitable issue for its possible consequences on public health. In order to manage the ambient air quality, there are several methodologies with each having some specific advantages and constrains. Improvement of ambient air quality involves the basic approaches like emission reduction at source level, conversion of pollutants to a less damaging compounds and sequestration of pollutants. However, in order to manage the air quality, application of ornamental plants may be considered a well alternative approach. Although, it may not be imperative to consider plants as a sole alternative for urban ambient air quality management, but certainly it may useful to manage air quality for a small confined area, especially in case of indoor air. This paper reviews the possible application of ornamental plants, which may be trees, shrubs or herbs for its possible applications to regulate air quality. Some selective plant species has also been recommended based on its air pollution tolerance index.
\end{abstract}

Keywords Ambient Air Quality, Ornamental Plants, Pollution

\section{Introduction}

Air pollution had spread around the world like an evil with rapid urbanization and industrialization, it has resulted in various health problems for man such as respiratory, cardiovascular and ophthalmic diseases (Brunekreef and Holgate, 2002; Miller et al., 2007; Nandasena, 2010; Giles et al., 2011; Gudmundsson, 2011; Jamrozik and Musk, 2011). The significant air pollutants are suspended particles, gases, different ionizing radiation and noise. The gases include the oxidized and reduced forms of nitrogen, Carbon, $\mathrm{SO}_{2}, \mathrm{C}_{6} \mathrm{H}_{6}$,
Vapour, $\mathrm{O}_{3}, \mathrm{Hg}, \mathrm{C}_{12}$, and volatile phenols. The suspended particles include the various forms of PM2.5, PM10 particulate and heavy metals.

In the past few decades India has witnessed a revolution in technological and industrial advancement coupled with an unexpected explosion of population. The first two of these significant events our society improved with many of the material things. The scientific technology has made these developments possible and user friendly. However, during achieving our goals for material things, subsequent side effects of such technological developments on esthetic values, and the quality of our environment have received very little or no attention.

The increase in population, industrialization and commercialization in urban areas has led to a rapid repercussion in the surrounding environment. Ambient air pollution has become a matter of great concern, particularly in mega cities and urban areas and rapid industrial development coupled with emission from transport sector are recognized as the prime sources. The situation is alarming and gradually becoming more severe and it is expected to increase in near future to cope up with the population expansion (Banerjee et al., 2011). Therefore, development of an adequate management plan is one of the most basic requirements for the well beings of human, animals as well as for plants.

Shrubs play a significant role in monitoring and controlling the air pollution by effectively participating in the cycling of gases like $\mathrm{N}, \mathrm{CO}_{2}, \mathrm{O}_{2}$ and nutrients. Shrubs also provide large leaf area for absorption, impingement and accumulation of pollutants to reduce the pollution level. There are various way and means to mitigate the effect of air pollution. Air pollution has tremendous impact on health of humans as well as on plants. Planting of shrub and tree is an effective and easy way for air pollution control and treatment of environment (Nugrahani et al., 2012). Several plants used for in landscape for beautification act as bio-indicators of urban air quality (Mondal et al., 2011).

India is blessed with various agro-climatic regions and in every part of India almost different type of plants are grown. 
Every single plant not only looks different from others but also has enormous features and utilities. As it is estimated that Indian flora comprises of nearly 2000 species belonging to 150 families of flowering plants. The vast diversity ranks the $10^{\text {th }}$ in the world (Kishwan et al., 2009). In cities and industrial areas certain proportion of land can be managed by growing some ornamentals. These ornamentals either may be trees, shrubs, climbers, ground covers or grasses which occupy a certain proportion of landscaping and become an important and integral part of that area. Scientific management of landscape techniques and selection of plant species has also opened the doors to minimize the deleterious effects of air pollutions in these areas. The awareness of growing ornamental plants for improvement of air quality is lacking in developing countries like India and there is a complete neglect of air quality improvement planning in big cities and near the industrial areas across the country. In view of the above, this paper will find out the possibility of using ornamental plant as an alternative approach for the management of ambient air quality.

\section{Source and Effects of Ambient Air Pollutants}

With the gradual advancement of Indian economy, rapid industrialization and commercialization in urban areas have evoked a concern over its probable impacts on surrounding environment. Scientists have identified nearly 3000 different anthropogenic air pollutants and most of them are organic. Combustion sources, especially motor vehicles, emit different compounds. However, only for about 200 of the pollutants have the impacts been investigated. The ambient concentrations are determined for an even smaller number resulting in a major limitation for urban air quality management.

Some natural factor also affects the air quality viz. Volcano which produces chlorine, ash particles and sulphur. Wildfire produces carbon monoxide and smog. Pine plant produce volatile organic compounds. Cattle and other animal produce methane gas.

In urban areas, combustion of fossil fuels to generate electricity, in industrial processes, transportation and space heating is the predominant anthropogenic source of atmospheric air pollutants $\left(\mathrm{CO}, \mathrm{NO}_{2}, \mathrm{SO}_{2}\right.$, TSPM etc.). The burning of hydrocarbons in motor vehicle engines gives rise to $\mathrm{CO}_{2}, \mathrm{CO}, \mathrm{SO}_{2}, \mathrm{NO}_{x}$ in varying proportions and $\mathrm{C}_{2} \mathrm{H}_{4}$, as well as a variety of other hydrocarbons. Additional $\mathrm{SO}_{2}$ originates from domestic and industrial burning of fossil fuels. Industrial plants, such as chemical and metal-smelting plants, release $\mathrm{SO}_{2}, \mathrm{H}_{2} \mathrm{~S}, \mathrm{NO}_{2}$, and $\mathrm{HF}$ (hydrogen fluoride) into the atmosphere.

TSPM are diverse in physical and chemical properties depending on their source (stationary, mobile or natural), geography and meteorology of the particular area. The sources, characteristics and potential health effects of $\mathrm{PM}_{10}$ (particles with aerodynamic diameter less than $10 \mathrm{~mm}$ ) and $\mathrm{PM}_{2.5}$ (particles with aerodynamic diameter less than $2.5 \mathrm{~mm}$ or fine particles) are very different. Epidemiological studies emphasized that exposure to airborne particles with aerodynamic diameter less than $10 \mu \mathrm{m}$ (Respirable Particulate Matter, RPM) induce negative health impacts and adverse meteorological factors may aggravate such kind of exposure. In addition to these, particulates are also responsible for causing reduced visibility and changes in the nutrient balance both through wet as well as dry deposition processes.

Sulphur dioxide is one of the atmospheric pollutants that played a vital role in designating the ambient air quality of a place, since its emission occurs from various industrial sources besides fossil fuel thermal power stations. Sulphur dioxide is also produced by smelting of sulphide ores. Atmospheric sulphur is one of the prominent anthropogenic pollutants and $\mathrm{SO}_{2}$ level rises $4 \%$ annually. This trend of rises in $\mathrm{SO}_{2}$ level is parallel to global energy consumption. $\mathrm{SO}_{2}$ is also responsible for formation of sulphate aerosols, deposition of sulphate particles and generation of sulphuric acids droplets $\left(\mathrm{H}_{2} \mathrm{SO}_{4}\right)$ under the opposite atmospheric conditions. Sulphur dioxide produce a stinging smell and as a result it causes breathing problems in humans. Researches involving asthmatics indicated that significant proportion of population experience changes in pulmonary function and respiratory symptoms after very short periods of exposure to $\mathrm{SO}_{2}$ (WHO, 2005). Further, the effects of $\mathrm{SO}_{2}$ on plants are moderately understood. Primarily, the gas is absorbed into the mesophyll layer of the leaves through stomata and incurs toxicity due to its reducing properties which leads to chlorotic or brownish red colour of leaves, owing to chronic toxicity.

Nitrogen oxides are the by-products of fossil fuel combustion processes, therefore, emission from automobiles and power plants are significant contributors of atmospheric $\mathrm{NO}_{2} . \mathrm{NO}_{x}$ emissions in Indian region are growing at an annual rate of $5.5 \%$ per year. Irritation in the respiratory tract is the predominant impact associated with $\mathrm{NO}_{2}$ when it is converted to nitrates and nitric acid. However, protracted exposure may cause adverse impacts on the lung structure, metabolism and resistance against infections. $\mathrm{NO}_{x}$ is one of the pre-cursor of ground level ozone and both can affect crops and other plants. Nitrogen oxides are predominantly responsible of both acid precipitation and ground level ozone formation and both are well blamed for causing injury to plants. While nitric acid is responsible for only a smaller part of hydrogen ion $\left(\mathrm{H}^{+}\right)$concentration in wet and dry acid depositions, the contribution of nitrogen oxide emissions to acid deposition could be more significant.

Common Fluorides pollutant compounds are $\mathrm{F}_{2}, \mathrm{SiF}_{6}, \mathrm{CF}_{4}$, and $\mathrm{HF}$. The fluoride pollutants include $\mathrm{CaF}_{2}, \mathrm{NH}_{3} \mathrm{~F}$, $\mathrm{Ca}_{3} \mathrm{AlF}_{6}, \mathrm{AlF}_{6}, \mathrm{NaF}$ and $\mathrm{Na}_{2} \mathrm{SiF} . \mathrm{NaF}, \mathrm{AlF}_{6}$ and $\mathrm{NaAlF}_{6}$ act as a source of aerosol. Major sources of fluoride pollution are glassworks, steelworks, aluminium factories, brick kiln, ceramic factories and uranium smelters. Fluoride pollutant 
causes the adverse effects when absorbed by plants and ingested by herbivorous animals.

\section{Air pollution state in India}

Air pollution is one of the main significant causes of the human health problems. According to World Health Organisation, at present urban outdoor air pollution contributes approximately 1.3 million deaths worldwide. Central Pollution Control Board (CPCB) and the State Pollution Control Boards (SPCBs) are responsible for data collection on air quality and policy enforcement. Centre for Science and Environment analysed the data on state of air quality and trend in Indian cities. Main pollutants in India are nitrogen dioxide $\left(\mathrm{NO}_{2}\right)$, particulate matter $(\mathrm{PM})$, sulphur dioxide $\left(\mathrm{SO}_{2}\right)$, and carbon monoxide. Particulate level in some Indian cities is 5 time greater then safety limits. The PM10 level is a biggest and main reason of human health problem. During 2007 data published by National Ambient Air Quality Standard (NAAQS) more than $52 \%$ cities were at PM10 critical level (exceeding 1.5 times the standard), 36 cities with high levels (1-1.5 times the annual standard) and 19 cities at moderate level. Highest PM10 level was found in Indian cities like Mumbai, Bengaluru, Lucknow, Delhi and Faridabad with continuously increasing levels. (Hosamane et al., 2012)

\section{Ambient Air Pollution Management through Ornamental Plants}

Air quality depends on different factors, including the population density, the volume of traffic, the energy demand and the physical characteristics of the territory (i.e. geographical conformation, topography). The development of a coherent picture of national environmental trends and conditions requires the collection of sufficient data, the statistical analysis and integration of the information and the provision of complete, accurate and understandable presentations. An effective air quality assessment and management strategy involves the consideration of a number of complex physical, chemical, socio-economic, environmental (i.e. pollutant emissions) and meteorological factors. These complexities require that effective tools to be employed in developing and establishing the air quality standards and emission regulations. Among the various adopted approaches, use of plants for the removal of ambient air pollutants has considerable potential. The fundamental purpose of air quality management through plants includes:

- To improve the air quality around the affected area

- To support and implement the developmental works

- To create good working conditions

- To provide good healthy condition for aged peoples and children

- To enrich the aesthetic value of a site

- To help to reduce other types of environmental pollutions

- To ensure safe and unhazardous journey

- To promote green-belt development

- To develop awareness in environment management among the peoples

Plants remove a significant amount of pollution from the atmosphere as part of their normal functioning. Plants reduce the concentration of greenhouse gases and their consequence on climate change.Apart from air pollution management, ornamental plants have a wide spectrum of uses in reduction of heat build-up, noise pollution and eliminating dust from air (Baiyewu et al., 2005). Additional benefit to grow ornamental plants for air pollution management is it gives aesthetic value. However, selection of ornamental species varied widely according to the location, purpose, adaptability to the particular soil etc. Different approach for choice of species should also be done for outdoor and indoor conditions. Different plant species vary considerably in their susceptibility to air pollutants. The identification and categorization of plants into sensitive and tolerant groups is important because the former can serve as indicators and the latter as sinks.

Table 1. Major outdoor air pollutants, pollutant sources and their effect on public health

\begin{tabular}{|c|l|l|}
\hline Outdoor pollutant & \multicolumn{1}{|c|}{ Pollutant sources } & \multicolumn{1}{|c|}{ Health problem } \\
\hline Carbon Monoxide & Burning diesel, petroleum and wood & $\begin{array}{l}\text { Increases confusion, sleepiness, low blood oxygen level, } \\
\text { slow reflexes }\end{array}$ \\
\hline Carbon dioxide & Burning oil, coal and natural gases & $\begin{array}{l}\text { Lowers oxygen levels, vision defects, reduces respiratory and } \\
\text { brain functions, }\end{array}$ \\
\hline Nitrogen dioxide $\left(\mathrm{NO}_{2}\right)$ & $\begin{array}{l}\text { Burning fuels, electricity generation plus vehicle } \\
\text { engines, }\end{array}$ & $\begin{array}{l}\text { defect in lung function and causes bronchitis in asthmatic } \\
\text { children, toxic }\end{array}$ \\
\hline Sulphur dioxide $\left(\mathrm{SO}_{2}\right)$ & industrial processes, and Burning fossil fuels & $\begin{array}{l}\text { eye irritation and respiratory inflammation, asthma attacks, } \\
\text { mucus secretion, decreases pulmonary function. }\end{array}$ \\
\hline Ozone $\left(\mathrm{O}_{3}\right)$ & $\begin{array}{l}\text { photochemical smog produced by the interaction of } \\
\text { sunlight and air pollutants }\end{array}$ & $\begin{array}{l}\text { breathing difficulties and } \\
\text { asthma, colds, pneumonia }\end{array}$ \\
\hline $\begin{array}{c}\text { Suspended particulate } \\
\text { matter }\left(\mathrm{PM}_{10}, \mathrm{PM}_{2.5}, \mathrm{SPM}\right)\end{array}$ & $\begin{array}{l}\text { Mixture of solid and liquid organic plus inorganic } \\
\text { materials including nitrates, sulphate, } \\
\text { carbon,sodium chloride, ammonia, mineral dust and } \\
\text { water }\end{array}$ & $\begin{array}{l}\text { Disrupts lung's gas exchange function and respiratory } \\
\text { illness }\end{array}$ \\
\hline
\end{tabular}


Research conducted by National Aeronautics and Space Administration (NASA), USA revealed that plants can be useful to clean indoor air. These scientists and other vigorous advocates say that plants have been cleaning the earth's atmosphere for millions of years and may be adopted as a most reasonable method for indoor air pollution control. Through photosynthesis, plant uptake carbon dioxide from the atmosphere and release oxygen. A team of NASA researchers tested the effect of fifteen house plants on three pollutants known to be present in spacecrafts. These same three pollutants viz. benzene, formaldehyde and trichloroethylene are present in homes and office buildings with furnishings, office equipment and some building materials as a primary source of emission. Under controlled conditions, certain houseplants were found to remove as much as $87 \%$ of indoor air pollutants within 24 hours. Further, it was revealed that more air that is allowed to circulate through the roots of the plants, the more effective they are at cleaning polluted air (Adopted from http://www.sti.nasa.gov/tto/Spinoff2007/ps_3.html)

\section{Mechanism of Air Quality Improvement through Plant System}

There are four main ways in which plants improve air quality parameters. These are:

\section{a) Reduction of Temperature:}

There is a direct relationship exists between the emission of many pollutant and/or ozone forming chemicals with atmospheric temperature. Ozone forming chemicals are also reported to decrease with reduction in air temperature. Plant has a direct effect on temperature, incident radiation, radiation absorption, surface roughness, wind velocity, relative humidity and surface albedo. Trees contribute towards cooler summer temperature. These changes help to create a microclimate in surrounding areas which has the ability to alter the pollutant concentrations in urban and industrial areas (Nowak et al., 1998).

\section{b) Removal of Air Pollutant:}

The principle process by which plants removed gaseous air pollution is through the stomata, though some gases are also removed by other plant organs. Absorbed gases diffuse into intercellular space react with inner surface of leaves, may be absorbed by water to form acid. Suspended air particle intercepts with the leaf surface, adsorbed on the leaf and dropped to the ground during leaf or twig fall or rain fall (Smith, 1990). It is reported that a large healthy tree $(>77 \mathrm{~cm}$ diameter) remove approximately 70 times more air pollution annually than small healthy trees which having diameter less than $8 \mathrm{~cm}$ (Nowak, 1994).

\section{c) Emission of Volatile Organic Compounds (VOC $)$ :}

Each and every plant emits certain amount of volatile organic compounds $\left(\mathrm{VOC}_{\mathrm{s}}\right)$ in the atmosphere. These $\mathrm{VOC}_{\mathrm{s}}$ are mainly responsible for the formation of ozone and carbon monoxide. However, in the presence of low nitrogen dioxide $\mathrm{VOC}_{\mathrm{s}}$ actually remove ozone (Crutzen et al., 1985). $\mathrm{VOC}_{\mathrm{s}}$ emission rates dependent upon the species and nine genera have been reported to have very high $\mathrm{VOC}_{\mathrm{s}}$ emission rate; among them Eucalyptus, Salix, Casuarina are important.

\section{d) Energy Effects on Building:}

Tress reduces the building energy by lowering temperatures through shading during the summer and blocking winds during winter (Heisler, 1986); however, shading effect may lead to increase energy use during winter while during summer energy use may increase or decrease in the buildings situated near the sea shore. Therefore, proper knowledge of tree placement near the vicinity of the buildings is required to achieve maximum benefit.

\section{Plant Symptoms in Response to Air Pollution Exposure}

Leaves absorb and accumulate pollutants from air and help to reduce the pollution level in the atmosphere. Plants provide an enormous leaf area for impingement. Certain changes in morphological, anatomical and physiological characteristics of plants have been reported when plant experienced air pollution exposure. The rate and total amount of pollutant taken up from the air can affect photosynthesis, respiration, growth, yield, leaf conductance and leaf longevity. All of these factors in trees adversely affect the canopy carbon fixation and biosynthesis of chlorophyll. Air pollutants affect the plants even in very low concentration ( 0.1 to $55 \mathrm{ppm}$ ). However, plant species differ in their sensitivity level to air pollutants. Plants symptoms in response to air pollution are of two types chronic and acute depend upon the extent of exposure. Chronic injury result by low level pollutant exposure. Chronic symptoms usually do not kill tissue. Chronic symptoms characterized by stripping, yellowing, dwarfing or growth loss. Acute injury is due to plant exposure to high level of pollutant. Acute symptom characterized by dead tissue in particular area. Sometime whole leaf or even plant death also occurs. Loss of chlorophyll, bronzing and reddening of the leaves is the commonly associated symptoms related with ozone exposure; whereas, upon the long exposure of $\mathrm{SO}_{2}$, broad leaved species produced dark brown inter-veinal bifacial necrosis spots on the leaf lamina (Tingey et al., 1973).

Some factors that determining the extent of plant damage are:

- Kind of pollutant

- Concentration of pollutants

- Distance from sources

- Meteorological condition

- Length of exposure 
- Some other significant factor are Season, Maturity of plant tissue, air drainage, soil moisture and nutrient supply, species of plant grow and land topography.

\section{Selection Criteria of Ornamental Plants for Improvement of Air Quality}

The trees should be tolerant to air pollutants present in the area

- The plants should be native to the area, be evergreen, rough bark, ecological compatible, large leaves, low water requirement, sunken stomata, inhabitant, minimum care, having minimum leaf fall.

- Plants producing large and spreading canopy should be preferred.

- The leaves should possess good surface area to provide maximum impinging surface for continued efficient adsorption and absorption of pollutants. Leaf characteristics should be amenable to particle collection like hairy, sticky etc.

- The plants having fast growing habit should be preferred.

- The plants have the ability to maintain, hydrological and ecological balance of that particular region.

- Plants should be tolerant to air pollution. Should have high APTI (Air Pollution Tolerance Index value)

- Keeping in view the climatic conditions, status of soils and vegetation types in and around the selected site the species shall be selected.

\section{Ornamental Plant Species Ideal for Improvement of Outdoor Air Quality}

The effectiveness of a plant suitable for air quality improvement determined with the air pollution tolerance index (APTI) value (Singh et al., 1991). APTI denotes capability of a plant to combat against air pollution. APTI is used by the landscapers for selection of plant that tolerate air pollution. The plants which have higher index value are tolerant to air pollution and can be utilized to mitigate pollution, while plants with low index value show less tolerance and can be used to indicate levels of air pollution (Singh and Rao, 1983). Changes in parameters such as ascorbic acid, total chlorophyll, relative water content and $\mathrm{pH}$ of leaf extract are determined to evaluate the degree of tolerance to air pollution by a plant species (Agbaire, 2009). Very little work has been carried out all over the world to find out most suitable species for air pollution management. Some plants are categorized as high, medium and low tolerance to air pollution on the basis of APTI value. The APTI index ranges are:

$\begin{array}{lll}\text { - } & 0 \text { to }<1 & \text { Most sensitive } \\ \text { - } & 1 \text { to } 16 & \text { Sensitive } \\ \text { - } & 17 \text { to } 29 & \text { Intermediate } \\ & 30 \text { to } 100 & \text { Tolerant }\end{array}$

(Singh and Rao, 1983).

\section{Source of Air Pollutant in Indoor Condition}

The major source from which air pollutant generated in indoor conditions are combustion, house hold waste, asbestos-containing insulation, wet and damp carpet, cabinetry and furniture made of certain pressed wood, chemicals, building materials and bioeffluents. Formaldehyde, $\mathrm{CO}, \mathrm{SO}_{2}, \mathrm{NO}_{2}$, and tobacco smokes are the byproduct generated from combustion in indoor conditions. Beside these, several chemical compounds such as cosmetics, deodorant, disinfectant, mosquito repellant, central heating and cooling system and humidification device when used by the householders are also hazardous for indoor air quality.

Table 2. Effects of various pollutant and concentration on plants:-

\begin{tabular}{|c|c|l|}
\hline Pollutant & Dose & \\
\hline Fluorides & Cumulative effect & Necrosis of leaves tip \\
\hline \multirow{2}{*}{ Ozone } & Sever & Bleaching, necrosis and collapse of leaf \\
\cline { 2 - 3 } & Mild & Premature ageing, suppressed growth and flecks on upper surface \\
\hline \multirow{2}{*}{ Sulfur dioxide } & Sever & Skeletonized leaves and necrosis \\
\cline { 2 - 3 } & Mild & Inter-venal chlorotic bleaching of leaves \\
\hline Ethylene & Mild & Leaf abscission, epinasty \\
\hline Nitrogen dioxide & Mild & Leaf bleaching and suppressed growth \\
\hline PAN & Mild & Suppressed growth, bronzing of lower leaf area and young leaf more affected. \\
\hline
\end{tabular}




\section{Selection Criteria of Ornamental Plants for Improvement of Indoor Air Quality}

- The plants should have some property to absorb air pollutant

- Select ornamentals according to the taste of the householder

- $\quad$ Easy to grow, less care and less input requirement

- Plants should have slow growing habit

- Shade tolerant plants should be selected

- Plant should not show any allergic and toxic effect

- Effective against wide range of spectrum

\section{Ornamental Plant Species Ideal for Improvement of Indoor Air Quality}

Current researches exhibit that ornamental plants can drastically reduce levels of stress, adverse health impacts as they have the potential to sequester harmful indoor air pollution. International space station (NASA) discovers that several house plants have ability to remove various toxic gases such as ammonia, formaldehyde, toluene and volatile organic compound $\left(\mathrm{VOC}_{\mathrm{s}}\right)$ from the environment. Researchers have now identified four "super ornamental plants" which every workplace should have to clean up indoor air (Cruz et al., 2014). A recent study revealed that ornamental indoor plants have ability to remove harmful $\mathrm{VOC}_{\mathrm{s}}$ from indoor air. The process through which indoor plants effectively remove harmful $\mathrm{VOC}_{\mathrm{s}}$ from the air called phytoremediation. Plants absorb toxic gases from air into their leaves and then translocated into root, whereas different microbes break them. Indoor plants also add biological and aesthetic compound to interior space by increasing the relative humidity and decreasing the dust accumulation. Removing the dust particles, decreasing potential allergy-inducing particles and increasing the relative humidity, induce relaxing effect. Apart from $\mathrm{VOC}_{\mathrm{s}}$, Benzene and toluene can also be sequestered by plants effectively. The research team tested different common indoor ornamental plants for their ability to remove indoor pollutants. Of the species tested, purple waffle plant (Hemigraphis alternata), English ivy (Hedera helix), waxy leaved plant (Hoya carnosa) and Asparagus fern (Asparagus densiflorus) were rated best for removing air pollutants. Beside these plants, following ornamental house plants are also found suitable to clean the indoor air.

\section{Needs for air Quality Management}

The most essential need is to discover and use of alternate non-polluting source of energy in a strategic way like solar energy, the most abundant and crucial source of energy for country like India, Hydrogen gas and natural gas fuel. Most accurate strategy is to transform the transportation system to natural gas, especially in megacities. Air quality in industrial area can be improved by using clean development mechanism.

Table 3. Ornamental house plants suitable for improving indoor air quality

\begin{tabular}{|c|c|c|c|}
\hline Name of the plant & Family & Growth habit & Light requirement \\
\hline Dypsis lutescens & Araceae & Erect, small, & Sun to semi shade \\
\hline Dendrobium (orchid) & Orchidaceae & Small plant & Sun to semi shade \\
\hline Dracaena & Liliaceae & Small plant & Sunny-semi shade \\
\hline Hedera helix & Araliaceae & Vigorous climber & Semi-shade \\
\hline Dieffenbachia & Arecaceae & Small plant & Semi-shade \\
\hline Nephrolepis obliterata & Lomariopsidaceae & Small plant & Semi-sun - extreme shade \\
\hline Rhapis excelsa & Areceae & Small palm & Semi-sun \\
\hline Chlorophytum comosum & Liliaceae & Medium plant & semi-shade to shade \\
\hline $\begin{array}{l}\text { Spathiophyllum } \\
\text { Aloe vera }\end{array}$ & $\begin{array}{c}\text { Areceae } \\
\text { Xanthorrhoeaceae }\end{array}$ & $\begin{array}{l}\text { Small palm } \\
\text { Small plant }\end{array}$ & $\begin{array}{c}\text { Semi-shade } \\
\text { Sun to semi shade }\end{array}$ \\
\hline
\end{tabular}

[Cristiano et al., 2016, Orwell et al., 2006; Lohr et al., 1994 and Wood et al., 2006] 
Table 4. Plants recognized for improvement of outdoor air quality

\begin{tabular}{|c|c|c|c|}
\hline Name of the plant & Family & Growth habit & Environmental importance \\
\hline \multicolumn{4}{|c|}{ Plants having high APTI value (30-100) } \\
\hline Pongamia Pinnata & Leguminosae & Small tree & Suitable for avenues \\
\hline Pithecellobium dulce & Fabaceae & Large tree & Suitable for road planting \\
\hline Holoptelea integrifolia & Ulmaceae & Large tree & Suitable for road planting \\
\hline Saraca indica & Leguminosae & Small tree & Suitable for avenues \\
\hline Sorbus aria & Rosaceae & Medium tree & Suitable for industrial area \\
\hline Acer campestre & Sapindaceae & Medium tree & Suitable for industrial area \\
\hline Pinus nigra var. maritima & Pinaceae & Large tree & Suitable for hilly areas \\
\hline Ficus nitida & Moraceae & Small tree & High dust capture capacity \\
\hline Eucalyptus globules & Myrtaceae & Large tree & High dust capture capacity \\
\hline Ficus infectoria & Moraceae & Medium tree & Suitable for avenues \\
\hline Psidium guajava & Myrtaceae & Small tree & Suitable for avenues \\
\hline \multicolumn{4}{|c|}{ Plants having medium APTI value (17-29) } \\
\hline Ficus rumphii & Moraceae & Large tree & Suitable for road side \\
\hline Azadirachta indica & Meliaceae & Large tree & Suitable for road side \\
\hline Grevillea robusta & Proteaceae & Large tree & Suitable for road side \\
\hline Ficus benghalensis & Moraceae & Large tree & Suitable for road side \\
\hline Ficus religiosa & Moraceae & Large tree & Suitable for road planting \\
\hline Ziziphus jujuba & Rahmnaceae & Large tree & Suitable for road planting \\
\hline Phyllanthus emblica & Euphorbiaceae & Large tree & Suitable for road planting \\
\hline Cassia fistula & Leguminosae & Medium tree & Suitable for avenues \\
\hline \multicolumn{4}{|c|}{ Plants having low APTI value (1-16) } \\
\hline Alstonia scholaris & Apocynaceae & Large tree & Suitable for road side \\
\hline Cassia siamea & Leguminosae & Low growing & Suitable for road side \\
\hline Bauhinia variegata & Leguminosae & Small tree & Suitable for avenues \\
\hline Caesalpinia pulcherrima & Leguminosae & Large tree & Suitable for road side \\
\hline Delonix regia & Leguminosae & Large tree & Suitable for road side \\
\hline Michelia champaca & Magnoliaceae & Medium tree & Suitable for industrial area \\
\hline Populus spp. & Salicaceae & Large tree & Suitable for industrial area \\
\hline Psidium cattleyanum & Myrtaceae & Medium tree & Suitable for industrial area \\
\hline Tradescantia & Commelinaceae & Small plant & Suitable for industrial area \\
\hline Petunia & Solanaceae & Small plant & Suitable for industrial area \\
\hline Madhuca latifolia & Sapotaceae & Small plant & Suitable for avenues \\
\hline Clerodendron infortunatum & Verbenaceae & Small plant & Outdoor condition of a house \\
\hline Eupatorium odoratum & Asteraceae & Small plant & Suitable for road side \\
\hline Hyptis suaveolens & Lamiaceae & Small plant & Outdoor condition of a house \\
\hline Polyalthia longifolia & Annonaceae & Medium tree & Suitable for avenues \\
\hline
\end{tabular}

[Beckett et al., 2000; Freer-Smith et al. 2004; Rzepka et al., 2005; Pandey, et al., 2005;

Lakshmi et al., 2008; Tripathi et al., 2009 and Jyothi and Jaya, 2010]

In air quality some obvious research needs. Many ecological and basic physiological studies of the climatic condition and effect on change in atmosphere are required. Monitoring programme also required for assessment of current actual condition and rate of change of air quality. Other pressing need is to control the atmospheric pollution and air quality is institutional management in India are:

- Encourage the private sector to identify need for more investment in air quality assessment and monitoring tool. Training facilities, capacities and calibration equipment are required. 
- It is essential to start institutional capacity building in air pollution and quality monitoring for those countries which do not have this facilities and strengthen for those which have already. It involves the following factors:

I Regulation and standards

II Government support and interest

III Stack-holders and awareness

IV NGO

$\mathrm{V}$ Viabilities and monitoring tools

\section{Conclusions}

The applicability of ornamental plants as an approach for air quality management and several plant species can be used, based on their APTI value and recommended based on their adaptability for different locations. It is well understood that such ornamental plants are well applicable as a supplementary approach for improvement of air quality and therefore it was felt necessary to adapt such practices in urban environment.

\section{REFERENCES}

[1] Agbaire, P.O. 2009. Air pollution tolerance indices (APTI) of some plants around Erhoike-Kokori oil exploration site of Delta State, Nigeria. International Journal of Physical Sciences, 4(6): 366-368.

[2] Baiyewu, R.A.; Amusa, N.A.; and Olayiwola, O. 2005. Survey on the use of ornamental plants for environmental management in Southwestern Nigeria. Research Journal of Agriculture and Biological Sciences, 1(3): 237-240.

[3] Banerjee, T., Barman, S.C. and Srivastava, R.K. 2011. Application of air pollution dispersion modeling for source-contribution assessment and model performance evaluation at Integrated Industrial Estate-Pantnagar. Environmental Pollution, 159(4): 865-875.

[4] Beckett, K.P.; Smith, P.F. and Taylor, G. 2000. Effective tree species for local air quality management. Journal of Arboriculture, 26(1): 12-18.

[5] Brunekreef, B. and Holgate, S.T. 2002. Air pollution and health. The Lancet, 360(2): 1233 - 1242.

[6] Cristiano, G., Murillo-Amador, B., andDe Lucia, B. 2016. Propagation Techniques and Agronomic Requirements for the Cultivation of Barbados Aloe (Aloe vera (L.) Burm. F.)-A Review. Frontiers in Plant Science, 7.

[7] Crutzen, P.J.; Delany, A.C.; Greenberg, J.; Haageson, P.; Heidt, L.; Lueb, R.; Pollok, W.; Seiler, W.; Wartburg, A. and Zimmerman, P. 1985. Tropospheric chemical composition measurements in Brazil during the dry season. Journal of Atmospheric Chemistry, 2: 233-256.

[8] Cruz, M. D., Christensen, J. H., Thomsen, J. D., \& Müller, R. 2014. Can ornamental potted plants remove volatile organic compounds from indoor air? - a review. Environmental
Science and Pollution Research, 21: 13909-13928.

[9] Freer-Smith, P.H.; El-Khatib A.A. and Taylor, G. 2004. Capture of particulate pollution by trees: a comparison of species typical of semi-arid areas (Ficus nitida and Eucalyptus globulus) with European and North American species. Water, Air, and Soil Pollution, 155: 173-187.

[10] Giles, L.V.; Barn, P.K.N.; Romieu, I.; Mittleman, M.A.; Eeden, S.; Allen, R.; Carlsten, C.; Stieb, D.; Noonan, C.; Smargiassi, A.; Kaufman, J.D.; Hajat, S.K.T.; \& Brauer, M. (2011).

[11] From Good Intentions to Proven Interventions: Effectiveness of Actions to Reduce the Health Impacts of Air Pollution. Environmental Health Perspectives, Vol.119, No.1, ( January 2011), pp. 29-36, ISSN 0091-6765

[12] Gudmundsson, G. (2011). Respiratory Health Effects of Volcanic Ash with Special Reference to Iceland. A review. The Clinical Respiratory Journal, Vol.5, pp. 2-9, (January 2011), ISSN 1752-6981

[13] Heiser, G.M. 1986. Energy savings with trees. Journal of Arboriculture, 12(5): 113-125.

[14] http://www.sti.nasa.gov/tto/Spinoff2007/ps_3.html date of retrieval 20.08.2011.

[15] Hosamane, S.N. 2012. Removal of Arsenic by Phytoremediation - A Study of Two Plant Spices. International Journal of Scientific Engineering and Technology, Vol.1, No.5, (November 2012), pg: 218-224, ISSN: 2277-1581.

[16] Jamrozik, E. and Musk, A.W. (2011). Respiratory Health Issues in the Asia-Pacific Region: An Overview, Respirology, Vol.16, No.1, (January 2011), pg.: 3-12, ISSN 1440-1843.

[17] Jyothi, S.J. and Jaya, D.S. 2010. Evaluation of air pollution tolerance index of selected plant species along roadsides in Thiruvananthapuram, Kerala. Journal of Environmental Biology, 31: 379-386.

[18] Lakshmi, P. S.; Sravanti, K.L. and Srinivas N. 2008. Air pollution tolerance index of various plant species growing in industrial areas. The Ecoscan, 2(2): 203-206.

[19] Lohr, V.L.; Goodwin, G.K. and Pearson-Mims, C.H. 1994. Effect of interior plants on relative humidity and air borne particulate matter in indoor environment. HortScience, 29: 504.

[20] Miller, K.A.; Siscovick, D.S.; Sheppard, L.; Shepherd, K.; Sullivan, J.H.; Anderson, G.L.; \& Kaufman, J.D. (2007). Long-Term Exposure to Air Pollution and Incidence of Cardiovascular Events in Women. The new england journal of medicine, Vol. 356, No. 5, (February 2007), pp. 447-458, ISSN: 0954-7762

[21] Kishwan, J.; Pandey, R. and Dadhwal, V.K. 2009. India's Forest and tree cover: contribution as a carbon sink. Technical Paper. I.C.F.R.E., New Forest, Dehradun - 248006 (Uttarakhand) India.

[22] Mondal, D. Gupta, S and Datta, J. K (2011). Anticipated Performance Index of Some Tree Species Considered for Green Belt Development in an Urban Area. Plant Science, 2(4):99-106

[23] Nandasena, Y. L. S.; Wickremasinghe A. R. \& Sathiakumar N. (2010). Air Pollution and Health in Sri Lanka: a Review of Epidemiologic Studies. BMC Public Health, Vol.10, (June 
2010), Available from

http://www.biomedcentral.com/1471-2458/10/300)

[24] Nowak, D.J. 1994. Air pollution removal by Chicago's urban forest. In: McPherson, E.G., D.J. Nowak and R.A. Rowntee. Chicago's urban Forest Ecosystem: Results of the Chicago Urban Forest Climate Project. USDA Forest Service General Technical Report NE-186. pp. 63-81.

[25] Nowak, D.J., McHale P.J., Ibarra, M., Crane, D., Stevens, J., and Luley, C. 1998. Modeling the effects of urban vegetation on air pollution, In: Air Pollution Modeling and Its Application XII. (S. Gryning amd N. Chaumerliac, eds.) Plenum Press, New York, pp. 399-407.

[26] Nugrahani, P. Prasetyawati, E.T, Sugijanto, O and Pumobasuki, H (2012). Asian Journal of Biological Sciences, 3(2):298-302.

[27] Orwell, R.L.; Wood, R.A.; Burchett, M.D.; Tarran, J. and Torpy, F. 2006. The potted plant microcosm substantially reduces indoor air VOC pollution: II. Laboratory study. Water, Air and Soil Pollution, 177: 59-80.

[28] Pandey, S.K.; Sharma, A.P.; Prajapati, S.K. and Tripathi, B.D 2005. Screening of heavy metals in the ambient air of a subtropical industrial area, using leaves of Ficus infectoria: A keystone species. In Books of Abstracts, Third International Conference on Plant and Environmental Pollution, $29^{\text {th }}$ Nov.-2, Dec., 2005. NBRI, Lucknow, India. p. 9 SI/P-23.

[29] Rzepka, M.A.; Cuny1, D.; Davranche, L.; Cazier, F.; Denayer, F.O. and Haluwyn, C.V. 2005. Air quality assessment in an industrial area in France using monitoring plants. In Books of
Abstracts, Third International Conference on Plant and Environmental Pollution, 29 ${ }^{\text {th }}$ Nov.-2, Dec., 2005. NBRI, Lucknow, India. p. 9 SI/O-17.

[30] Singh, S.K. and Rao, D.N. 1983. Evaluation of the plants for their tolerance to air pollution. In: Proceedings of the Symposium on Air Pollution Control. Indian Association for Air Pollution Control, IIT, Delhi. pp. 218-224.

[31] Singh, S.K.; Rao, D.N.; Agrawal, M.; Pandey, J. and Narayan 1991. Air pollution Tolerance index of Plants. Journal of Environment Management, 32: 45-55.

[32] Smith, W.H. 1990. Air pollution and forests. New York. Springer-Verlag. 618p.

[33] Tingey, D.T.; Reinert, R.A.; Dunning, J.A. and Heck, W.W. 1973. Foliar injury responses of eleven plant species to ozone/sulphur dioxide mixtures. Atmospheric Environment, 7(2): 201-206

[34] Tripathi, A.; Tiwari, P.B.; Mahima and Singh, D. 2009. Assessment of air pollution tolerance index of some trees in Moradabad city, India. Journal of Environmental Biology, 30(4): 545-550.

[35] WHO. 2005. Air Quality Guidelines: Global Update 2005, Report on a Working Group meeting, Bonn, Germany, 18-20 October 2005, WHO, Regional Office for Europe, Copenhagen, Denmark pp 484.

[36] Wood, R.A., Burchett, M.D.; Orwell, R.L.; Alquezar, R. and torpy, F. 2006. The potted-plant microcosm substantially reduces indoor air $\mathrm{VOC}_{\mathrm{s}}$ pollution: I. Office field study. Water, Air and Soil Pollution, 175: 163-180. 